\title{
Potret Strategi Going Concern UMKM Pandai Besi Celurit Bermotif Madura
}

Jurnal Akuntansi Terapan Indonesia Vol 4 No 2 Hal 117-126 October 2021

\section{Affiliation:}

Universitas Trunojoyo Madura, Indonesia

\section{*Correspondence:}

yuni.rimawati@trunojoyo.ac.id

This Article is Avalilable in:

https://journal.umy.ac.id/index.php/jat i/article/view/10602

DOI:

https://doi.org/10.18196/jati.v4i2.106 02

\section{Citation:}

Rimawati, Y., \& Ervanto, A. (2021).

Potret Strategi Going Concern UMKM

Pandai Besi Celurit Bermotif Madura. Jati: Jurnal Akuntansi Terapan Indonesia, 4(2), 117-126.

\author{
Article History \\ Received: \\ 26 June 2021 \\ Reviewed: \\ 06 Agustus 2021 \\ Revised: \\ 11 September 2021 \\ Accepted: \\ 26 October 2021 \\ Topic Article: \\ Accounting for SMEs
}

\author{
Yuni Rimawati*, Adi Darmawan Ervanto
}

\begin{abstract}
:
This study aims to provide an overview of the unique going concern strategy of Tokang pandhih Jokotole (read: SMEs blacksmith) which produces patterned sickles so that these MSMEs are able to survive and even have been traversed by several generations. This study used a configurative ideographic studies case study approach to analyze the data. The conclusion of this study is that Haji Masduri implements a strategy to maintain product quality to maintain customer trust. The development of a business into a business that has a business license with the "Jokotole" brand is a government facility that is accepted by Haji Masduri. In business operational management, Haji Masduri carries out a specialization strategy for production work, a gratuity system (profit sharing) based on the selling price of patterned sickle workers, and "utilizing the network" owned to obtain quality raw materials without leaving the house (place of business). The strategy for maintaining cash flow carried out by Haji Masduri is the production system for orders and a 50\% down payment. The impact of the maintained product quality, Haji Masduri can apply a strategy to determine the selling price without the bargaining process of ordering a patterned sickle.
\end{abstract}

Keywords: Business Strategy, Going Concern, SMEs, Cultural Products.

\begin{abstract}
Abstrak:
Penelitian ini bertujuan untuk memberikan gambaran keunikan strategi going concern pandai besi tokang pandhih Jokotole yang memproduksi celurit bermotif sehingga UMKM ini mampu bertahan bahkan sudah dijalan oleh beberapa generasi. Penelitian ini menggunakan pendekatan studi kasus configurative ideographic studies untuk menganalisis data. Simpulan penelitian ini adalah Haji Masduri menerapkan strategi menjaga kualitas produk untuk menjaga kepercayaan pelanggan. Pengembangan usaha menjadi usaha yang memiliki ijin usaha dengan brand "Jokotole" adalah fasilitas Pemerintah yang diterima Haji Masduri. Setelah memiliki ijin usaha, Haji Masduri dapat mengakses lebih banyak fasilitas dari Pemerintah. Dalam manajemen operasional bisnis Haji Masduri menjalankan strategi spesialisasi kerja bagian produksi, sistem upah persenan (bagi hasil) berdasarkan harga jual pada tenaga kerja celurit bermotif, dan "memanfaatkan jaringan" yang dimiliki untuk memperoleh bahan baku ayng berkualitas tanpa meninggalkan rumah (tempat usaha). Strategi menjaga cash flow yang dilakukan oleh Haji Masduri adalah dengan sistem produksi pesanan dan uang muka 50\%. Dampak dari kualitas produk yang terjaga, Haji Masduri dapat menerapkan strategi penentuan harga jual tanpa proses tawar menawar dari pemesan celurit bermotif.
\end{abstract}

Kata Kunci: Strategi Bisnis, Going Concern, UMKM, Produk Budaya. 


\section{PENDAHULUAN}

Celurit adalah salah satu senjata khas yang identik dengan masyarakat Madura. Pada beberapa pandangan, identiknya celurit dengan masyarakat Madura ini lebih pada sisi kekerasan dan pertumpahan darah (carok). Celurit juga merupakan suatu produk ysng tentunya terdapat "pengaturan" agar sampai pada titik transaksi penjualan. Proses pembuatan dan pengaturan dan ini menjadi dasar utama menentuan "harga" celurit. Proses penentuan harga jual merupakan upaya untuk menyeimbangkan keinginan untuk memperoleh manfaat sebesar- besarnya baik dari sisi pembeli berdasarkan "nilai" dari produk maupun dari sisi penjual yang berdasarkan perolehan "profit" yang tinggi (Rimawati dan Auliyah, 2019).

Berdasarkan kegunaannya celurit dibedakan menjadi celurit yang digunakan untuk kegiatan sehari-hari dan senjata atau sekep. Berdasarkan bahan dan proses pembuatan, celurit dibedakan lagi menjadi dua macam yaitu celurit yang tidak bermotif dan celurit bermotif.

Proses produksi celurit, terutama celurit bermotif merupakan usaha padat karya. Para pembuat celurit sangat membutuhkan keahlian khusus, yang tidak ada pendidikan formalnya. Selain itu proses pembuatan celurit bermotif yang 100\% handmade maka dipastikan akan ada perbedaan pada setiap produk yang dihasilkan. Dengan kata lain, tenaga kerja memiliki peranan yang sangat besar untuk mendapatkan produk jadi yang berkualitas untuk celurit. Sehingga manajemen tenaga kerja ini menjadi faktor penting dalam sistem produksi, penentuan harga jual dan menjaga kualitas celurit bermotif.

Desa Kolpo adalah suatu desa yang terkenal dengan pandai besi penghasil celurit bermotif. Pandai besi penghasil celurit bermotif oleh masyarakat Madura dikenal dengan tokang pandhih. Desa Kolpo berada di Kecamatan Batang-batang, Kabupaten Sumenep. Sumenep adalah Kabupaten yang terletak disisi paling timur Pulau Madura. Berdasarkan BPS Kecamatan Batang-batang dalam angka 2018 (BPS Kabupaten Sumenep, 2018), pada sektor industri, Desa Kolpo memiliki angka paling tinggi pada industri logam dasar, besi dan baja dengan angka sebesar 87 rumah tangga. Sedangkan menurut Buku Desa Kolpo pada tahun 2017, jumlah penduduk menurut mata pencaharian pada tukang kayu/batu/ besi memiliki angka sebanyak 193 penduduk.

Dari banyaknya tokang pandhih yang ada di Desa Kolpo, terdapat satu usaha tokang pandhih yang cukup terkenal dan paling besar yaitu tokang pandhih Jokotole. Usaha ini didapat secara turun-temurun, yang dianggap sebagai warisan dari orangtua dan nenek moyang pemilik. Pemilik usaha tokang pandhih Jokotole adalah Haji Masduri yang merupakan generasi ke tiga. Haji Masduri mengelola usaha ini sejak tahun 1987 dan sampai saat ini.

Berdasarkan komposisi aset, permodalan dan tenaga kerja yang terlibat, maka usaha Tokang pandhih Jokotole dapat digolongkan menjadi UMKM (Usaha Mikro, Kecil, dan Menengah) karena hanya memiliki 5 orang karyawan. Umumnya pelaku UMKM bertanggung jawab mulai kegiatan produksi, keuangan sampai pemasaran. Pada UMKM Tokang pandhih Jokotole, faktor tenaga kerja merupakan hal yang sangat krusial, karena pemilik juga berperan dalam hal manajemen usaha dan juga sebagai tenaga kerja. Haji Masduri, pemilik usaha Tokang pandhih Jokotole memiliki peran menyeluruh mulai dari produksi sampai layanan purna jual untuk menjaga keberlanjutan usahan-ya. Tanggung jawab yang menyeluruh terkait perkembangan usahanya menjadikan topik going concern pada UMKM menarik untuk diteliti.

Prinsip going concern suatu usaha dapat berjalan pada era perdagangan saat ini sangat dipengaruhi oleh kemampuannya berinovasi dan berdaya saing (Taan, 2016). Inovasi dan penguatan daya saing ini dapat dilakukan dengan berbagai cara, salah satunya memasukkan unsur seni dan budaya ke dalam produk. Penelitian terdahulu dari Amaliah \& 
Sugianto (2018) menemukan bahwa nilai-nilai Si Pitung mampu membawa pencapaian going concern dari aktivitas ekonomi masyarakat Betawi. Selain itu Penelitian dari Rimawati \& Auliyah (2019) juga menemukan bahwa inovasi sistem penggajian dengan menggunakan sistem bagi hasil bagi pengrajin batik genthongan dan strategi penentuan harga dengan mentransfer filosofi proses pembuatan batik pada pembeli adalah inovasi dan keunggulan bersaing JC Collection.

Tujuan penelitian ini adalah memotret keunikan strategi going concern Tokang pandhih Jokotole yang memproduksi ce-lurit bermotif sehingga UMKM ini mampu bertahan bahkan sudah dijalan oleh beberapa generasi. Suatu produk jika ingin bersaing maka harus dibuat sesuai dengan design yang sesuai dengan keingian konsumen. Hal ini sangat sesuai dengan filosofi pembuatan celurit bermotif, karena sebagian besar produksinya berdasarkan pesanan. Penelitian ini diharapkan memberikan gambaran going concern entitas bisnis UMKM jenis manufaktur menjalankan operasional dan manajemen bisnis yang masih kental dengan unsur budaya lokal dan mampu bertahan sampai tiga generasi. Penelitian ini juga diharapkan dapat memberi gambaran praktis bahwa sesungguhnya produk berbasis budaya mempunyai kemampuan bertahan yang luar biasa, karena produk ini melekat pada kehidupan sehari-hari suatu masyarakat.

\section{METODE PENELITIAN}

Penelitian ini menggunakan metode kualitatif studi kasus. Hal ini disesuaikan dengan tujuan penelitian, yaitu mendapatkan pemahaman yang lebih menyeluruh tentang strategi going concern Tokang pandhih yang memproduksi celurit bermotif sehingga UMKM ini mampu bertahan bahkan sudah dijalan oleh beberapa generasi. Kamayanti (2016:74) men-jelaskan bahwa penelitian studi kasus merupakan studi yang mengeksplorasi suatu masalah dengan batasan yang terperinci, memiliki pengambilan data yang mendalam, dan menyer-takan berbagai sumber informasi. Penelitian ini menggunakan metode studi kasus karena penelitian ini berfokus pada pemahaman dinamika yang ada dalam pengaturan tunggal Haji Masduri dalam menjalankan usahanya, Tokang pandhih Jokotole memberikan gambaran keunikan strategi going concern pandai besi tokang pandhih Jokotole yang memproduksi celurit bermotif sehingga UMKM ini mampu bertahan bahkan sudah dijalan oleh beberapa generasi. Untuk mencapai tujuan penelitian tersebut pendekatan studi kasus yang digunakan adalah "Configurative ideographic Studies". Kamayanti (2016:77) menjelaskan bahwa studi kasus dengan pendekatan Configurative ideographic Studies merupakan studi kasus yang bertujuan menjelaskan apapun yang sedang diteliti melalui insentisitas interpretasi tinggi atas elemen-elemen yang membentuk keseluruhan unit.

Obyek penelitian ini adalah usaha tokang pandhih Jokotole yang dimiliki oleh Haji Mas-duri. Usaha ini dijalankan oleh Haji Masduri secara turun menurun dari kakek beliau. Tokang pandhih Jokotole merupakan Tokang pandhih terlama dan terbesar yang terletak di Desa Kolpo, Kecamatan Batang-batang, Kabupaten Sumenep. Data yang digunakan dalam penelitian ini adalah data primer. Data tersebut dikumpulkan berdasarkan hasil wawancara dengan Haji Masduri, pemilik usaha Tokang pandhih Jokotole sebagai informan utama. Haji Masduri telah 33 tahun menjalankan usahanya, yaitu Tokang pandhih Jokotole. Selain informan utama, penelitian ini juga menggali informasi dari informan lainnya seperti karyawan dan pembeli di Tokang Pandhi Jokotole sebagai bentuk triangulasi data. Informan pendukung penelitian ini adalah Bapak Sarwini yang telah bekerja selama 10 tahun pada Haji Masduri dan Bapak Misnoto (pembeli celurit bermotif Tokang Pandhi Jokotole).

Pengumpulan data melalui wawancara dilakukan secara semi terstruktur melalui pengamatan aktivitas usaha Tokang Pandhi Jokotole. Hal ini juga merupakan upaya yang dilakukan peneliti untuk membina hubungan baik agar dapat memperoleh kemudahan mendapatkan informasi dari para informan. 


\section{HASIL DAN PEMBAHASAN}

\section{Gambaran Umum UMKM Tokang pandhih Jokotole}

Tokang pandhih Jokotole merupakan salah satu Tokang pandhih yang tertua dan terbesar di Kampung Kayu Kembang, Desa Kolpo, Batang-batang, Sumenep. Berdasarkan penuturan dari pemilik, usaha ini didapat secara turun temurun dan mulai dijalankan oleh Haji Masduri (generasi ketiga) sejak tahun 1987. Keahlian beliau didapat dari sang ayah karena ikut bekerja pada sejak kecil. Diawal Haji Masduri mengelola usahanya, tokang pandhi Jokotole banyak memproduksi alat-alat pertanian yang terbuat dari besi.

Pada tahun 1999-an di Sumenep terjadi peristiwa Supardi. Peristiwa ini merupakan sebutan para warga dengan adanya aliran sesat di kala itu. Hingga sekarang peristiwa tersebut belum diketahui kebenarannya, tetapi berkah kejadian ini, tokang pandhih Jokotole pendapatkan keuntungan dengan dibanjiri banyaknya pesanan. Setelah terjadinya peristiwa Supardi sampai dengan tahun 2005, tokang pandhih Jokotole mulai mengalami perubahan. Untuk pesanan pun sudah tidak lagi hanya sebatas peralatan bertani saja. Pada waktu ini, celurit dan celurit bermotif sudah menjadi produk yang paling banyak dipesan. Seiring berjalannya waktu, pada tahun 2007 tokang pandhih Jokotole berhasil mempunyai pelanggan tetap dari luar Madura, yaitu Situbondo. Sejak saat itu, tokang pandhih Jokotole mulai terkenal di daerah dari luar Madura bertambah, seperti Banyuwangi, Jember, Pasuruan, Bali. Haji Masduri menjelaskan, produknya dapat diterima dan dikenal karena mempunyai keungulan berupa ketajaman yang tahan lama. Keunggulan ini sebagai bentuk hasil pemilihan bahan baku yang berkualitas dan cara pengolahannya.

Usaha Haji Masduri ini sudah terdaftar menjadi Usaha Mikro Kecil Menengah (UMKM) pada 21 November 2011. Terdaftarnya Tokang pandhih Jokotole ini menjadi UMKM mempunyai cerita tersendiri sehingga pada akhirnya nama Jokotole dijadikan sebagai brand. Sebelum terdaftar menjadi usaha UMKM dan sebelum diberi nama Jokotole, Haji Masduri mengikuti lomba yang diadakan oleh Pemerintah Provinsi Jawa Timur terkait Pameran Pandai Besi se Jawa Timur. Dalam lomba ini, produk Haji Masduri terpilih sebagai pemenang juara satu tingkat Provinsi Jawa Timur. Produk yang diikut sertakan pada lomba tersebut adalah celurit bermotif yang "ditandai" dengan ukiran kecil di produknya dengan nama "Haji Masduri". Berhasil keluar sebagai pemenang, penitia mendata kelengkapan administratif celurit bermotif Haji Masduri dan ternyata masih belum terdaftar sebagai produk dari suatu entitas usaha. Berangkat dari kejadian tersebut, kemudian Bapak Haji Masduri mendaftarkan usahanya menjadi UMKM dan diberi nama "Jokotole", dengan produk unggulan celurit bermotif.

Haji Masduri menjelaskan, nama Jokotole diambil dari nama pemuda Madura yang dipercaya memiliki kesaktian dan perjalanan hidup yang luar biasa. Jokotole menurut leganda masyarakat Madura merupakan satu-satunya orang dari sekian banyak empu-empu (tokang pandhih) yang mampu melekatkan patri pada gerbang Kerajaan Majapahit.

Haji Masduri sering mendapatkan "fasilitas" dari pemerintah untuk mengenalkan produknya dengan mengikuti pameran-pameran. Dalam mengikuti pameran tersebut, Haji Masduri tidak mengeluarkan biaya, berikut penjelasan beliau:

"Saya sering mas ikut pameran, biasanya megikuti pameran yang di adakan di Sumenep seperti hari jadi kabupaten Sumenep.Sering juara. Setiap pameran tersebut tidak mengeluarkan biaya sepeserpun. Bahkan saya juga pernah diundang beberapa acara di Pamekasan, Blitar, dan lain-lain untuk presentasi menyampaikan usaha celurit ini."

Bantuan dari pemerintah ini tidak hanya dalam hal pemasaran dengan ikut serta dalam pameran-pameran, H. Masduki juga diundang oleh Pemerintah Kabupaten Sumenep 
untuk mengikuti pelatihan managemen se Kabupaten Sumenep. Berdasarkan keteranganketerangan Haji Masduri, proses perkembangan usahanya menjadi usaha yang berlegilitas hukum (menjadi UMKM) dengan brand "Jokotole" merupakan buah dari mendapatkan fasilitas pemerintah.

\section{Strategi Going Concern UMKM Tokang Pandhih Jokotole}

Going concern (keberlanjutan usaha) merupakan salah satu dari 4 asumsi dasar dalam penyusunan laporan keuangan (Totanan, 2018). Asumsi ini berarti perusahaan harus konsisten beroperasi agar memiliki pendapatan sehingga perusahaan memiliki kemampuan mempertahankan kelangsungan hidupnya. Hal ini bisa diperoleh melalui pendapatan yang berujung pada perolehan laba yang menjadi dasar dalam melanjutkan usahanya di masa depan. Going concern juga berarti perusahaan selalu diasumsikan tidak bermaksud melikuidasi atau menurunkan skala usahanya secara material. Dengan menggunakan konsep akuntansi untuk mencapai tujuan tersebut maka sebuah entitas harus mampu bertumbuh atau menghasilkan laba untuk bisa bertahan.

Totanan \& Paranoan (2018) berpandangan going concern adalah prinsip keabadian. Jika disandingkan dengan prinsip akuntansi, keabadian dalam pandangan Totanan dan Paranoan (2018), suatu hal akan tersisa ada walau manusia (sebagai individu) telah berganti. Guston (2014) mengatakan going concern berkaitan dengan teknologi, perubahan, dan life cycle. Sehingga dapat ditarik benang merah berdasarkan pendapat Guston (2014) dan Totanan dan Paranoan (2018) hal-hal terkait going concern adalah kemampuan entitas untuk bertumbuh, kepekaan terhadap perubahan, life cycle, karakterisitik dan seni mengatur operasional entitas.

Berdasarkan hasil observasi dan wawancara, penerapan strategi going concern yang digunakan adalah membuat usahanya memiliki legalitas hukum sebagai UMKM sehingga usahanya dapat memanfaatkan fasilitas-fasilitas yang diberikan oleh pemerintah untuk pengusaha UMKM serta dapat mengakses bantuan-bantuan yang dialokasikan oleh pemerintah secara khusus untuk UMKM. Selain itu, usaha untuk going concern yang dilakukan oleh UMKM Tokang Pandhih Jokotole terdapat dalam keunikan proses produksi dalam menjaga kualitas produk, Manajemen Bahan Baku, serta sistem penjualan dan penentuan harga produk.

\section{Proses Produksi Celurit Bermotif}

Produk yang dihasilkan tokang pandhih Jokotole sangat beragam, mulai dari peralatan pertanian dan rumah tangga, hingga celurit bermotif (senjata khas Madura yang mempunyai Keindahan dan nilai spiritual). Celurit bermotif inilah produk unggulan tokang pandhih Jokotole. Memproduksi celurit bermotif, sangat menjanjikan dalam dunia tokang pandhih, karena produk yang dihasilkan bukan hanya sekedar senjata melainkan buah kreatifitas sehingga menjadi karya seni. Untuk bentuknya dan pamornya pelanggan dapat meminta sesuai keinginan. Inilah mengapa pandai besi Jokotole memilih menggunakan proses pesanan dalam memproduksi celurit bermotif.

Pemantik terkenalnya produk celurit bermotif produksi tokang pandhih Jokotole adalah setelah memenangkan lomba yang diadakan oleh Pemerintah Provinsi Jawa Timur. Menurut penjelasan Haji Masduri, Celurit bermotif karyanya berhasil menjadi pemenang karena kualitasnya. Salah satu faktor pendukung kualitas tersebut menurut Haji Masduri karena bahan baku yang digunakan dan proses pembuatan yang ilmunya diperoleh secara turun temurun.

Tokang pandhih Jokotole menggunakan baja sebagai bahan campuran yang akan dicampurkan dan diolah bersama dengan besi, sehingga produk yang dihasilkan akan jauh lebih tajam serta tahan lama. Inilah yang menjadi salah satu keunggulan khusus yang dimiliki tokang pandhi Jokotole, oleh karena itu tokang pandhih lain tidak akan mudah untuk 
menirunya. Sebab keunggulan khusus ini merupakan ilmu yang dimiliki oleh Bapak Haji Masduri diajarkan oleh ayah beliau yang didapat secara turun temurun. Terlebih pada celurit bermotif, tidak semua pandai besi bisa membuatnya dikarenakan terdapat ritual khusus seperti berpuasa sampai bacaan tertentu dalam proses pembuatannya. Segala usaha pembuatan, berupa keunggulan khusus sampai dengan ritual khusus tersebut dilakukan agar kualitas celurit bermotif yang diproduksi tokang pandhi Jokotole mempunyai nilai, baik nilai keindahan, nilai kegunaan, nilai manfaat dan nilai budaya.

Dalam proses pembuatan celurit bermotif, Haji Masduri melakukannya sendiri dengan dibantu tiga karyawan. Untuk meminimalisasi risiko, Haji Masduri melakukan sendiri pencampuran bahan antara besi dan baja. Tahap pencampuran ini melalui proses pemanasan besi dan baja. Pertama, besi akan dipanaskan terlebih dahulu lalu dipukul-pukul, setelah memanaskan baja, dan mencampurkannya pada besi sebelumnya serta pukul-pukul kembali. Untuk tahap ini, Haji Masduri dibantu oleh bapak Sudiryo dengan tugas memukul besi dan baja yang dipanaskan hingga mendapatkan bentuk yang sempurna.

Mengacu pada Wiyata (2002), ada bentuk-bentuk celurit yang populer bagi masyarakat Madura, yaitu: 1. takabuwan (memiliki bentuk yang serasi antara lengkungan dan panjangnya); 2. dang-osok (berbentuk buah pisang yang ukurannya lebih panjang dari ukuran rata-rata pisang biasa); 3. tekos bu-ambu (bentuknya seperti seekor tikus sedang diam); 4. Lancor ajem (berbentuk ekor ayam dan bergagang sangat panjang ); 5. bulu ajam (mirip bulu ayam); 6. kembang turi (bunga turi), 7. Monteng (tulang ekor). Menurut Haji Masduri di Tokang pandhih Jokotole bentuk yang paling banyak dipesan adalah celurit lancor ajam. Haji Masduri menjelaskan, celurit berbentuk lancor ajam merupakan ciri khas Kabupaten Sumenep, penggambaran senjata yang dimiliki oleh Arya Wiraraja, Adi Pati Sumenep pada Abad 13.

Setelah proses pencampuran besi dan baja, Haji Masduri melanjutkan pada proses pembentukan. Pada proses ini Haji Masduri dibantu oleh bapak Sarwini. Bapak Sarwini bertugas membuat tangkai dan pemasang slop (penghubung besi dengan tangkai) pada celurit bermotif. Untuk proses pembentukan motif dilakukan oleh Haji Masduri sendiri. Proses ini merupakan tahapan yang krusial dalam produksi celurit bermotif. Pada tahapan ini dilakukan oleh Haji Masduri. Sama seperti bentuk, motif dibuat berdasarkan permintaan pemesan.

Setelah proses pembentukan, proses selanjutnya adalah penghalusan dan penajaman. Proses ini dilakukan pada alat yang bernama gerendra yang di dalamnya terdapat bahan bernama keker. Karyawan yang bertugas pada bagian ini adalah bapak Sunahwi. Biasanya pada proses ini senjata yang telah jadi akan dikikis agar semakin halus, sehingga dapat mempercantik penampilan senjata yang dibuat serta mempermudah dalam pemberian pamor.

Yang menarik dari proses pembuatan celurit bermotif ini adalah adanya ritual-ritual yang tidak ditemui pada proses produksi pada umumnya. Ritual ini berpedoman pada prembun (bahasa Madura yang bermakna kitab). Menurut keterangan Haji Masduri yang menentukan ritual tersebut adalah beliau selaku pembuatnya. Haji Masduri juga menceritakan bahwa terkadang dari pembeli juga menyerahkan bacaannya ke beliau. Berikut penjelasan Haji Masduri terkait hal ini:

"Dalam membuat celurit bermotif ada ritual yang dilakukan. Setiap orang melakukan pemesan celurit selesainya tidak bisa cepat. Namun masih ada ritual dalam menentukan hari, tanggal atau bulan, dan wuku atau pancawara. Wuku ini seperti galungan kuningan, langker, mondoseo, dll. Wuku itu ya mingguan itu. Kalau pancawara itu, misalnya senin. Ada senin manes, senin paeng, pons, legi, kliwon. Dalam penentuan ritual itu biasanya disesuaikan dengan ilmu prembun (seperti kitab). Dalam hal ini yang menentukan ritual itu bisa langsung dari saya selaku pembuatnya, saya 
tetap berpedoman pada prembun tersebut. Terkadang dari pembeli juga menyerah bacaannya ke saya. Misalnya pembeli tersebut membawa baca-bacaannya lalu saya yang baca, biasanya bacanya beda-beda misal saya mau memotong lempengan besi bacaannya ini, mau mengganggubungkan besi dan bajanya ini, jadi beda-beda. Ada juga dalam penentuan waktu tersebut pembeli pergi ke kyai. Tujuannya ini untuk memperkuat bela diri dan mencari keselamatan atas kehendak Allah."

Sebenarnya tokang pandhih Jokotole memiliki 5 (lima) karyawan lain, namun bukan sebagai karyawan tetap. Lima orang ini bekerja saat tokang pandhih Jokotole harus menerima banyak pesanan. Karyawan tambahan ini bekerja untuk memenuhi target (deadline) produksi. Sesungguhnya selain celurit bermotif Haji Masduri juga memproduksi produk lain yaitu celurit biasa atau senjata tajam lain untuk alat pertanian dan rumah tangga. Hal ini sebagai manajemen untuk menjaga kelangsungan usahanya

Dari uraian di atas, disimpulkan bahwa bahan baku utama celurit bermotif adalah campuran besi dan baja. Pencampuran besi dan baja ini dilakukan oleh Haji Masduri sendiri untuk menjaga kualitas. Haji Masduri juga telah melakukan pembagian kerja (spesialisasi) pada karyawannya untuk memaksimalkan kinerja dan menjaga kualitas produknya. Tetapi sistem pembagian kerja yang terlampau eksklusif juga memiliki kekurangan, yaitu jika tenaga kerja tersebut berhalangan, maka proses produksi tersebut akan terhenti karena orang lain tidak dapat menggantikannya.

\section{Manajemen Input Produksi Celurit Bermotif}

UMKM Tokang Pandhih Jokotole merupakan UMKM yang berjenis usaha manufaktur. Suatu usaha digolongkan menjadi perusahaan menufaktur jika terdapat proses berubah atau menambahkan manfaat pada bahan baku menjadi sesuatu yang akan dijual. Proses tersebut dapat terjadi jika terdapat biaya (cost). Dalam pandangan akuntansi biaya, biaya adalah pengorbanan yang dilakukan terlebih dahulu sebelum menerima manfaatnya (Hansen \& Mowen, 2013). Dalam proses merubah tersebut terdapat tiga input produksi, yaitu bahan baku, tenaga kerja, dan factory overhead. Input produksi bahan baku dan tenaga kerja merupakan prime cost atau sumber biaya utama dari suatu produk, apabila salah satunya tidak tersedia maka proses produksi tidak akan berjalan. Sedangkan tenaga kerja dan biaya tidak langsung lainnya merupakan biaya perubah yaitu hal yang bertugas melaksanakan proses produksi tersebut.

Pembuatan celurit bermotif memang memerlukan bahan baku khusus, tetapi Haji Masduri tidak kesulitan dalam mendapatkan bahan baku tersebut. Bahan baku utama berupa lempengan besi dan baja dipasok oleh pasar loak di Surabaya. Seperti yang dijelaskan oleh Haji Masduri:

\footnotetext{
"Untuk bahan baku saya bekerja sama dengan pasar loak di Surabaya. Jadi saya tinggal hubungi, nanti dikirim ke rumah dan saya mentransfer uangnya. Biasanya saya melakukan pemesanan 1 bulan bisa 1 kali atau 2 kali. Saat melakukan pengiriman saya menggunakan ekspedisi."
}

Selain kerja sama dengan pasar Loak Haji Masduri juga bekerja sama dengan toking pandhih yang masih ada hubungan kekeluargaan dengannya yaitu H. Wardi. Berikut penjelasan beliau:

"Titip H. Wardi yang ada di Desa Lenteng jika beliau ke Surabaya saya di telepon, jadi saya langsung titip." 
Selain besi dan baja bahan lainnya yang sangat diperlukan adalah arang. Haji Masduri memiliki caranya sendiri untuk bisa mendapatkan arang. Bapak Haji Masduri mengambil arang dari para pembuat arang yang ada di sekitar Desa Kolpo. Tidak hanya mengambil satu pembuat arang saja, melainkan hampir semua pembuat arang dijadikan pemasok. Tentu tersebut karena ada beberapa kendala dalam mendapatkan arang dengan kualitas yang diinginkan, terlebih jika musim hujan. Saat musim hujan, para pembuat arang akan mengalami kesulitan dalam pengeringan. Sehingga dengan memiliki lebih dari satu pemasok arang akan menjaga ketersediaan persediaan arang tokang pandhih Jokotole.

Dari penjelasan ini dapat ditarik kesimpulan bahwa Haji Masduri memanfaatkan jaringan yang dimiliki untuk mendapatkan bahan baku (besi, baja dan arang) tanpa harus meninggalkan usahanya. Hal ini dapat dipahami karena Haji Masduri memiliki peran yang dominan dalam proses produksi, terutama celurit bermotif. Sehingga strategi memanfaatkan jaringan versi Haji Masduri ini sangat efektif.

Seperti yang diungkapkan sebelumnya, selain celurit bermotif Haji Masduri juga memproduksi produk lain. Haji Masduri juga telah melakukan spesialisasi kerja pada pegawainya. Selain itu Haji Masduri juga memisahkan tarif tenaga kerja yang mengerjakan produk celurit bermotif dengan produk lain. Berikut penjelasan Haji Masduri:

"Sistem penggajian ada 2 cara yaitu karyawan secara harian sebesar rp 100.000/ hari dan karyawan dengan sistem persenan yaitu sebesar 10\% setiap produk yang dibuat. Misalnya dalam pembuatan celurit bermotif sehari menghasilkan uang kurang lebih $\mathrm{rp}$ 2.300 .000 (harga jual celurit bermotif) dimana 10\% diberikan kepada masing-masing yang mengerjakan. Biasanya dikerjakan dua karyawan dengan sistem persenan. Jadi 1 karyawan yang persenan mendapatkan $R p 230.000$ kalau dua orang yang persenan berarti rp 460.000. Untuk waktu kerja berbeda, karyawan biasa kerjanya di mulai dari jam 08.00 sampai sore jam 16.00 atau jam 17.00. Kalau untuk karyawan yang persenan waktunya lebih lama mas, kadang dimulai setelah subuh sampai malam."

Sistem penggajian berbasis syariah yaitu bagi hasil (Wulaningrum \& Nisa, 2018) atau dalam bahasa Haji Masduri "persenan" dinilai efektif untuk tenaga kerja celurit bermotif. Hal ini karena celurit bermotif adalah produk yang 100\% hand made sehingga layak diklasifikasikan sebagai produk karya seni. Hal ini untuk meningkatkan kinerja pegawai baik dalam sisi waktu maupun mutu pengerjaan.

\section{Sistem Penjualan dan Penentuan Harga Celurit Bermotif}

Haji Masduri membuat celurit bermotif berdasarkan pesanan karena baik bentuk maupun motif disesuaikan dengan selera pemesan. Sedangkan penentuan harga jual produk adalah hak Haji Masdudi selaku pengrajin. Selain itu dalam persetujuan penjualan pembeli juga harus memberikan uang muka sebesar 50\% dari harga, sebagaimana penjelasan Haji Masduri:

"Motif pamor berdasarkan permintaan pelanggan, kadang pelanggan memesan dengan membawa contoh gambar secara langsung. Penentuan harga tetap dari saya tanpa adanya proses tawar-menawaran. Harga jual paling murah rp.750.000 sampai rp. 5.000.000 untuk celurit bermotif, kalau celurit biasa kan Cuma rp 70.000 - rp 95.000. Pelanggan juga harus membayar uang muka 50\% di awal pemesanan."

Haji Masduri juga menjelaskan dasar penentuan harga jual celurit bermotif adalah bahan baku dan motifnya, semakin susah motifnya semakin mahal. Sedangkan ritual-ritual khusus saat proses produksi yang dikerjakan langsung oleh Haji Masduri menurut beliau tidak mempengaruhi harga karena hal tersebut dinilai sebagai budaya yang sudah dilakukan 
turun-temurun. Berikut penjelasan Haji Masduri saat di konfirmasi tentang ritual-ritual khusus dan penentuan harga:

"Tidak ada, harga celurit tetap, karena ritualnya cuma baca-bacaan saja. Namun terkadang para pembeli memberikan tambahan uang kepada saya terkait pelaksanaan ritual tersebut. Dalam penentuan harganya tidak ada, seikhlasnya bagi orang yang membeli, kadang juga ada yang tidak memberi. lya, itu sudah kayak budaya, dari jaman ayah saya juga gitu."

Saat dikonfirmasi tentang pertumbuhan usaha Haji Masduri menjelaskan dengan berkelakar:

"Semakin meningkat permintaan dari para pelanggan ini bahkan dulu rumah saya masih masih terbuat dari bambu alhamdulillah sekarang sudah cukup memadai dari hasil usaha pembuatan celurit ini. Selain itu saya juga sudah Haji, anak saya sekarang kuliah dengan malanjutkan studi S2 di Yogyakarta."

Sedangkan sistem penjualan produknya masih menggunakan sistem tradisional yaitu pemasaran mouth to mouth dari pelanggan yang puas dengan hasil karyanya. Berdasarkan penjelasan dari Bapak Haji Masduri, orang mengenal tokang pandhih Jokotole karena kualitas produknya, sehingga membuat pembeli kembali lagi untuk membeli dan memesan lebih banyak hingga menjadi pelanggan. Dengan kata lain pemasaran produk tokang pandhih Jokotole berjalan dari mulut ke mulut pelanggan. Selain itu tanpa disadari H. Masduki dengan mengikuti kegiatan pemeran yang dilakukan oleh Pemerintah Daerah menjadikan produknya dikenal di luar Madura.

Sehingga dapat disimpulkan, walaupun sistem penjualan masih sangat tradisonal dan penentuan harga murni dari penjual penjualan tokang pandhih Jokotole terus meningkat. Hal ini karena penjual percaya pada kualitas baik akan menjadi berita baik dan tersebar luas, khusus untuk celurit bermotif dikerjakan berdasarkan pesanan. Bahkan berdasarkan penjelasan Haji Masduri, beberapa pelanggan celurit bermotif memberikan harga lebih dengan memberikan uang tambahan.

\section{KESIMPULAN}

Strategi pengembangan usaha tokang pandhih Haji Masduri untuk tetap going concern adalah menjadikan usahanya memiliki legalitas hukum (menjadi UMKM) dengan brand "Jokotole". UMKM Tokang Pandhih Jokotole kemudian memanfaatkan fasilitas pemerintah dengan mengikuti kegiatan pameran dan lomba terkait usaha dan kerajinan pandai besi. Dengan menjadi UMKM tokang pandhi Jokotole juga mendapat mengakses bantuan-bantuan lainnya.

Sistem penjualan meski masih sangat tradisonal yaitu dari mulut ke mulut namun berhasil membuat usaha ini tetap bertahan karena Haji Masduri konsisten menjaga kualitas produknya. Strategi untuk menjaga kualitas celurit bermotif yang dilakukan Haji Masduri adalah spesialisasi kerja bagian produksi dan sistem upah persenan (bagi hasil) berdasarkan harga jual celurit bermotif. Untuk efektifitas, strategi waktu Haji Masduri dengan meminimalisasi meninggalkan rumah yang juga tempat produksi untuk mendapatkan bahan baku dengan memanfaatkan jaringan yang dimiliki.

Strategi menjaga ketersediaan dana adalah dengan sistem produksi pesanan dan uang muka 50\%. Haji Masduri menerapkan standar kerja menjaga kualitas. Dampak dari kualitas produk yang terjaga, Haji Masduri dapat menerapkan strategi penentuan harga jual tanpa proses tawar menawar dari pemesan celurit bermotif. 
Penelitian ini memberikan gambaran bahwa UMKM yang memproduksi produk budaya dan hand made dapat terus bertahan dengan mengembangkan diri, menjaga kualitas produk dengan menjaga hubungan baik dengan tenaga kerja dengan sistem upah bagi hasil, menjaga ketersediaan dana, dan pemenuhan janji pada pelanggan. Dengan perubahan jaman dan cara pandang masyarakat pada saat ini dan produk celurit ini terus diminati adalah sebagai tanda bahwa masyarakat masih memiliki keterikatan pada budaya walaupun fungsi dari celurit tersebut mungkin telah berubah.

Penelitian ini tidak dapat memberikan gambaran secara terperinci (secara angka) tentang pertumbuhan usaha UMKM karena tokang pandhih Jokotole belum melakukan pencatatan akuntansi. Sehingga diharapkan penelitian selanjutnya terkait going concern UMKM dapat memberikan kontribusi terkait pertumbuhan usaha berdasarkan catatan keuangan dan bukti lainnya terkait pengembangan usaha, khususnya kelekatan budaya dari sudut pandang pembeli celurit bermotif.

\section{DAFTAR PUSTAKA}

Amaliah, Tri Handayani dan Sugianto. (2018). Konsep Harga Jual Betawian dalam Bingkai Si Pitung. Jurnal Akuntansi Multiparadigma JAMAL Volume 9 Nomor 1 Halaman 20-37, April 2018. https://doi.org/10.18202/jamal.2018.04.9002.

BPS Kabupaten Sumenep (2018). Kecamatan Batang-Batang dalam Angka 2018. https://sumenepkab.bps.go.id/publication/download.html?nrbvfeve $=Z m Z k N W J k M z R k N z$ JkZWVhMjgOMzFjM2Jk\&xzmn=aHR0cHM6Ly9zdW1lbmVwa2FiLmJwcy5nby5pZC9wd WJsaWNhdGlvbi8yMDE4LzA5LzI2L2ZmZDViZDM0ZDcyZGVIYTI4NDMxYzNiZC9rZW NhbWFOYW4tYmFOYW5nLWJhdGFuZy1kYWxhbS1hbmdrYSOyMDE4Lmh0bWw\%3D \& twoadfnoarfeauf $=\mathrm{MjAyMCOxMS0xNiAxNDoyNToxNw \% 3D \% 3D.} \mathrm{Accessed} \mathrm{November}$ 20, 2018.

Guston, D. H. (2014). Responsible Innovation: A Going Concern. Journal of Responsible Innovation, 1(2), 147-150. https://doi.org/10.1080/23299460.20 14.937904.

Hansen. R.Don. Mowen, M, Maryane 8th Edition. (2013). Cost Management: Accounting \& Control.

Kamayanti, A. (2016). Metodologi Penelitian Kuantitatif Akuntansi Pengantar Religiositas.

Rimawati, Yuni dan Robiatul Auliyah. (2019). Strategy of Selling Price, Innovation and Value Contained in Business of Batik Genthongan. International Confrence of Islamic Economic \& Busisness 6th, 2019. https://doi.org/10.2991/iconies-18.2019.68.

Taan, Hapsari. 2016. Pengaruh Inovasi Produk dan Harga Terhadap Keungulan Bersaing Usaha Karawo di Kota Gorontalo. Jurnal Ilmiah Bisnis\& Kewirausahaan. Vol 6 No 2.

Totanan, C. (2018). Pengaruh patronage buying motives terhadap prinsip going concern pada UMKM. Akuisisi: Jurnal Akuntansi, 14(1), 44-51.

Totanan, Chalarce dan Natalia Paranoan. 2018. Going Concern dalam Metafora Ondel-ondel. Jurnal Akuntansi Multiparadigma (JAMAL) Volume 9. Nomor 1. April 2018.

Wiyata, Latief. (2002). Carok, Konflik Kekerasan, dan Harga Diri Orang Madura . Yogyakarta: LkiS.

Wulaningrum, P. D., \& Nisa, A. (2018). Praktik Penerapan Akad Murabahah Dalam Pembiayaan Pensiun di Bank Syariah Mandiri. Jati: Jurnal Akuntansi Terapan Indonesia, 1(1). https://doi.org/10.18196/jati.010104. 